\title{
How the Self Became a Problem: A Psychological Review of Historical Research
}

\author{
Roy F. Baumeister \\ Case Western Reserve University
}

\begin{abstract}
In this article, historical evidence pertaining to selfhood is reviewed. A scheme of stages is delineated, according to which the modern self and its uncertainties have evolved. The historical data are then reviewed in connection with the following four major problems regarding the self: knowing and conceptualizing the self; defining or creating the self; understanding one's potential and fulfilling it: and relating the single self to society.
\end{abstract}

Modern psychology has shown considerable interest in understanding the self. Interest in problems of selfhood has spread from the clinicians to the humanistic psychologists and has even become a dominant feature of laboratory research. Indeed, if one surveys the extensive literatures on self-esteem (e.g., Baumeister \& Tice, 1985; S. C. Jones, 1973) self-awareness (e.g., Carver \& Scheier, 1981; Duval \& Wicklund, 1972), selfpresentation (e.g., Baumeister, 1982, 1986; Schlenker, 1980), self-verification (Swann, 1985), self-schemas (e.g., Markus, 1977; Markus \& Smith, 1981), self-handicapping (e.g., E. E. Jones \& Berglas, 1978), self-concept (e.g., Epstein, 1973; Gergen, 1971), and self-monitoring (e.g., Snyder, 1974), it is diffcult to escape the impression that the self must be ranked with dissonance and attributions as one of the fundamental issues that has concerned social and personality psychologists.

The problematic nature of selfhood has concerned laypersons as well as professionals. Popular books and movies commonly recognize the need to "find oneself" and to "be oneself." Erikson (1968) observed that the rapid popularization of the term identity crisis, originally a term of psychological jargon, denoted that there was already widespread general interest in the phenomena it described. The individual quest for personal fulfillment (self-actualization) has become increasingly accepted by the general society as a legitimate and important aspect of life.

It is plausible that the self simply has some ineffable fascination that has made it a perennial puzzle. One can read Kant and Descartes and even the ancient thinkers as if they were grappling with all these same issues of selfhood. A careful look at historical evidence suggests, however, that the concern with problems of selfhood is essentially a modern phenomenon. The medieval lords and serfs did not struggle with self-definition the way modern persons do.

I wish to thank D. McFarlin, D. Peabody, S. Hanson, B. Levy, S. Matthews, D. Stevenson, G. E. Swanson, D. Tice, and an anonymous reviewer for their criticisms and suggestions. Portions of this article are based on a recent book, Identity, by Roy F. Baumeister, Oxford University Press, 1986.

Correspondence concerning this article should be addressed to Roy F. Baumeister, who is now at the Psychology Department, University of Texas at Austin, Austin, Texas 78712.
My thesis is that the self has become a problem in the course of historical development. The present article reviews historical discussions of developments that shed light on how that happened. I have organized this article according to an a priori scheme of four problems pertaining to the self. These problems include how identity is actively or creatively defined by the person, what is the nature of the relationship between the individual and society, how does the person understand his or her potential and then fulfill it, and how and how well do persons know themselves.

The general scheme of historical eras can be outlined (and named) as follows. The late medieval period, from about the 11 th through the 15 th century, gradually developed a crystallized concept of the unity of the single human life. The early modern period (roughly 1500-1800) came to stress the distinction between the inner self and the outer self, to value individuality, and increasingly to recognize human development and change. During that era, Puritanism increased self-consciousness and recognized the possibility of self-deception. In the Romantic era (late 18th and early 19th centuries), persons began to seek and emphasize secular forms of fulfillment, and they acutely sensed a deep conflict between the individual and society. During the Victorian era (roughly 1830-1900), there were crises with regard to each of the four problems of selfhood I have mentioned. Early in the 20th century, themes of alienation and of devaluation of selfhood indicated concern over the individual's helpless dependency on society. Since World War II, individuals have accommodated to the changed social realities but have continued to grope for ideals and means of self-definition and fulfillment. (The general scheme and developments are outlined in Table 1.)

\section{Evidence}

The present discussion relies on two related types of evidence. One is historical data; the other is literature. The use of literature (especially fiction) as evidence for the problems and conflicts confronting human beings is based on the assumption that the literature of a given era uses themes and characters to portray current dilemmas of the human condition (see, for example, Houghton, 1957). Changes in thematic content and characterization from one era to the next, then, suggest changes in the human condition. The writing of lives, in biography and 
Table 1

Issues of Selfhood and Historical Stages

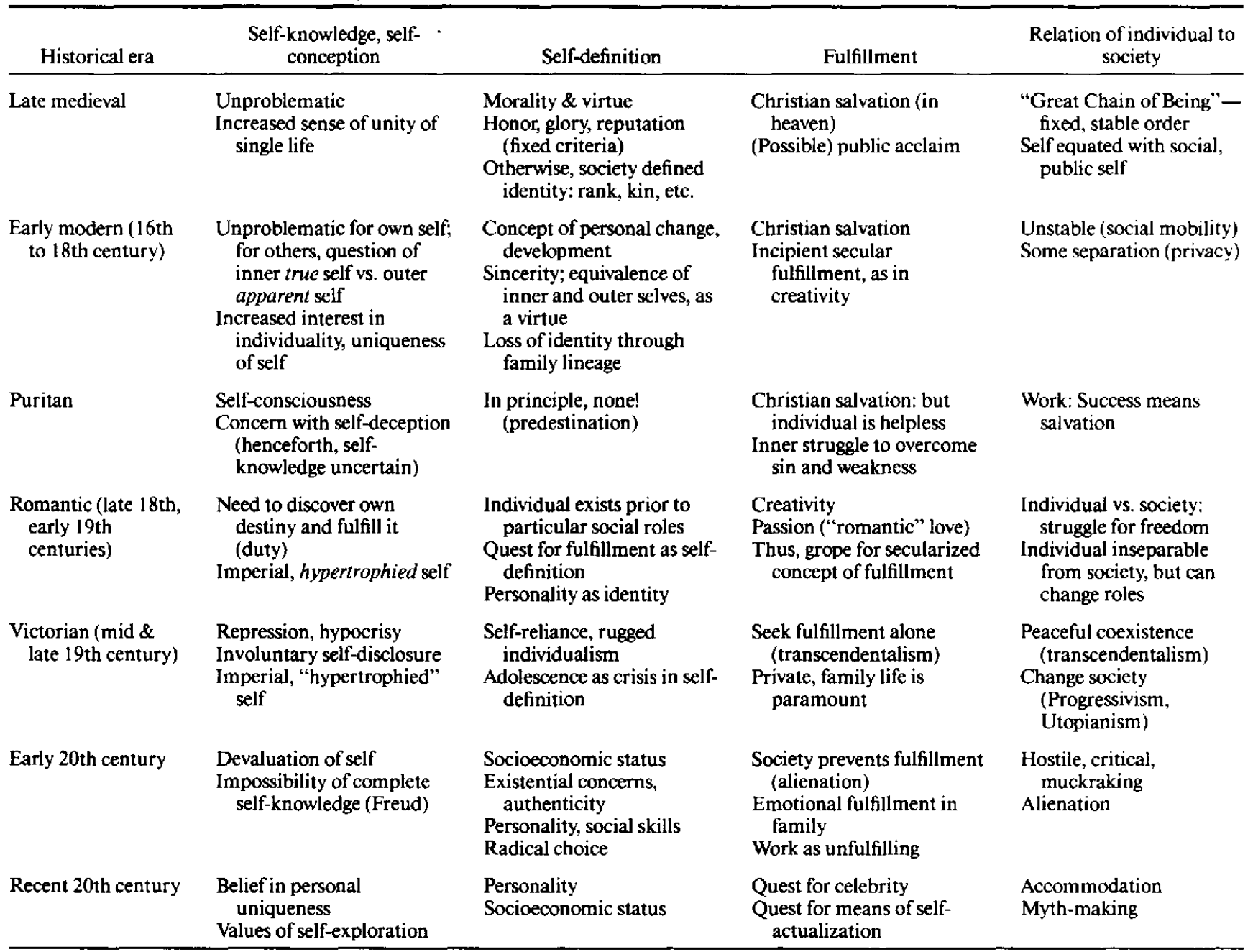

autobiography, is an important area of overlap of historical and literary evidence about selfhood.

The interpretation of both historical and literary evidence is necessarily more subjective than the interpretation of experimental findings. To prevent myself from generating the support for my own conclusions (as well as to prevent myself from making judgments I am not qualified to make), I shall rely exclusively on the work of historians and literary scholars, instead of on direct interpretation of evidence.

One danger of any review article is that the conclusions can be no more valid than the evidence surveyed, and perhaps this is especially true of an interdisciplinary review article. The reader must be doubly cautious of my psychological conclusions based on historical evidence, first because they are limited by the soundness of current historical research, and second because they are made by a psychologist rather than a historian. I have proceeded with this project despite these risks because the only apparent alternative is to ignore the research in other disciplines, which carries the opposite risk of depriving personality and social psychology of potentially valuable information and perspectives.
Needless to say, the generalizations in this article pertain to general trends rather than to universal patterns. The purpose is to understand the sequential development of problems of seifhood, not to formulate strict or rigid classification of persons by historical eras. Moreover, the research reviewed herein focuses on America, England, and France. Other European countries may have passed through similar stages at different times, but again, what is important is the developmental sequence, not the precise dates. My original intention was to restrict my research to American history. However, the recency of American history necessitated some reliance on data from Western Europe, especially England. The historical roots of American civilization would seem to justify this use. For present purposes, the most important divergence between English and American patterns was the differential timing of the influence of Puritanism, which flourished in America only after its defeat in England.

\section{Self-Knowledge}

Confidence in the human capacity for self-knowledge seems to have suffered a progressive deterioration over the past centu- 
ries. This development can be seen in the gradual elaboration of a concept of the self as something increasingly hidden, abstract, and elusive. The self ceased to be equated with observable behavior and commitments, and it came to be understood as the cause and owner of the visible phenomena.

\section{Review of Research}

Although the injunction to "know thyself" is articulated in ancient Greek philosophy, there is no reason to assume that selfknowledge posed the same problem for ancient Greeks as it does for modern citizens. Indeed, given MacIntyre's (1981) analysis of early concepts of person as purely functional, "know thyself" probably can and should be interpreted as advice to appraise one's talents and capacities accurately so as to be able to carry out one's duties effectively, with prudent judgment.

Late medieval awareness of selfhood was crude by modern standards, suggesting that self-knowledge was not regarded as an important problem. Hanning (1977) has noted that literature of the 11 th and 12 th centuries was just beginning to use devices based on the idea that different characters in a drama had different perspectives on the action. (Hanning's contention that such signs indicate true individuality seems an exaggeration, unless individuality is defined very loosely.) The increased awareness of the unity of the single life is suggested by several developments, particularly a change in popular Christian beliefs regarding death. Aries (1981) noted that early Christian beliefs and eschatology viewed salvation as collective, but that around the 12th century a concept of the Last Judgment spread that emphasized the judging of individual souls (also see Morris, 1972). All the events of the life added up to a moral and spiritual sum, and this totality decided the eternal fate.

There is little evidence that medievals engaged in introspection or experienced inner struggles. Indeed, Hanning (1977), in searching for inner struggles portrayed in medieval writings, could do no better than a poem in which the heroine pauses for a moment when confronted with conflicting imperatives. Weintraub (1978) observed that the remarkable scarcity of autobiographical writing during the Middle Ages is itself evidence of a disinterest in exploring the individual self. Weintraub found one exceptional person (Petrarch, in the 14th century) who showed introspective tendencies, but even this man (who was probably far ahead of his contemporaries) appeared to use introspection to appraise how well he matched the collective, general ideals, and not as a means toward individuation or selffulfillment.

Incipient introspection, awareness of separateness of different persons, and sense of unity of each single life all may be regarded as prerequisites for making self-knowledge into a problem. The late Middle Ages satisfied these prerequisites.

The next step toward making self-knowledge into a problem was to cease equating the self with its appearances. Trilling (1971) has asserted that it was the 16th century in which people first came to believe that the self was an inner or hidden space and was something to be distinguished from the way the person acted in public. Trilling described the 16th century society in England as obsessed with deception and pretense (cf. Auerbach, $1946 / 1974$, p. 86). Indeed, the concern with contrasts between misleading appearances and underlying realities was abundantly reflected in the philosophy, politics, and literature of that era, from Shakespeare to Machiavelli to Berkeley. The great rise in popularity of the theater in England and France reflected a new interest in acting and playing roles, although actors were not yet the culture heroes they are today. Trilling noted in particular the literary emergence of villains, in the sense of characters recognized as evil by the audience but not by the other characters in the drama.

An abstract, hidden self is harder to know and define than is a concrete, observable self. Therefore, the belief in a real self that is hidden, that is not directly or clearly contained in one's actions, can be regarded as a critical complication of selfknowledge. The inner nature of selfhood, which is regarded as axiomatic by much modern psychological thought, seems to have become a common conception first in the 16 th century.

At that time, however, the problem seemed to be to know the inner selves of others, not one's own self. Introspection flourished during the 16th century (Weintraub, 1978), but it does not seem to have been felt to be difficult or limited (also see Auerbach, 1946/1974, pp. 301-303). The difficulty of knowing the underlying motives of others is attested by the increasing stress on the new virtue of sincerity (Trilling, 1971). Sincerity is a kind of equivalence between the public appearance of the person and the inner self that is presumed to be hidden behind or underneath that appearance. Making sincerity into an important virtue reflected the new concern with and difficulty of inferring the hidden self from the overt acts and appearances.

With Puritanism, the difficulty of knowing underlying psychological realities was extended to self-knowledge. This may have developed in the following way. The Puritan doctrine of predestination meant that eternal damnation or salvation was already unchangeably fixed when the person was born. Calvin added parenthetically that there were ways of telling whether one was among "the Elect" or was destined to Hell instead. Although Calvin said not to dwell on whether oneself belonged to the Elect or not, it probably was hard for the typical Puritan to resist wondering about the most important feature of his or her eternal life (Weintraub, 1978). Therefore, as most historians seem to agree, Puritans became self-conscious to an unprecedented degree. Indeed, Whyte (1960) recorded that consciousness and self-awareness first came to be recognized as important concepts and values during the 17th century, as indicated in part by the first appearance of those terms (with the modern meaning) in English and German writings. A lifetime of selfscrutiny, however, tended to bring many Puritans to realize that they were especially seeking favorable signs, because they naturally wanted to believe themselves among the Elect. The possibility thus arose that they were deceiving themselves about their piety, faith, and virtue (Weintraub, 1978). Once the recognition of self-deception, and of motives for self-deception, became firmly established, self-knowledge was doomed to remain tentative and uncertain.

The contribution of the Romantic era to the difficulty of selfknowledge was primarily the emphasis on the unique, individual destiny and potential of each person, which that person was presumably obliged by some cosmic duty to discover and fulfill. I shall cover this development in greater detail later, in the section on fulfillment and potential. A second feature of this era was the expansion of the realm of the hidden self. For example, Anderson (1971) characterized the self of 19 th century literature as the hypertrophied self, and Sypher (1962) made a similar 
observation regarding the extended scope of the self at this time. Thus, the task of self-knowledge was increased: As the size of the self was deemed greater, there was more and more of the self to know. One area of expansion was personality. During the 19th century, personality (rather than social rank and roles) came to be increasingly regarded as a, even the, central aspect of the self. One source of evidence for this development is trends in biographical writing, which shifted to emphasize personal material (Altick, 1965). Indeed, Altick asserted that literary criticism during the 19th century began to use the work as a means for understanding the person who created it, which was a radical departure from traditional attitudes and approaches.

The extensiveness of the hidden parts of the self was increased by Victorian repressiveness. The habits of self-scrutiny (which by then were widespread), combined with the impossibly high moral standards, forced Victorians to become self-deceptive (cf. Houghton, 1957, although this observation is commonplace now). Indeed, it could be suggested that the extent of Victorian self-deception made it inevitable that some insightful person would eventually begin to see through it all, permitting the systematic accounting of techniques and motives for self-deception. Freud's accomplishment in this regard has been sufficiently influential that few people nowadays can regard the attainment of complete self-knowledge as a practical possibility. (Certain mysticisms may constitute exceptions.)

In this connection, it is interesting that Victorians believed the inner self would be revealed involuntarily, so one had to be constantly on guard. Sennett (1974) contended that people came to feel alarmed and threatened by the belief that others could deduce their personalities, including private thoughts and wishes, from looking at their clothes and other subtleties. By about 1850 , urban clothing styles had become painstakingly drab and inexpressive, and many Victorian women simply refused to go out in public in daylight for fear of being looked at (Sennett, 1974). The Victorian belief and fascination with the involuntary disclosure of emotion is exemplified by the popular Sherlock Holmes novels of that era and is probably behind Freud's (1905/1959) famous assertion that "Betrayal oozes from every pore."

Thus, the difficulty and the desirability of self-knowledge were well established cultural attitudes by the beginning of the 20 th century. It is not necessary to invoke any further developments during the 20th century to explain why self-knowledge is a problem. Two speculations deserve mention, however. First, the increasing failure and abandonment of religious faith may have deprived modern citizens of access to a fixed set of answers to problems in interpreting the self (e.g., Jung, 1928/1971; also see Rieff, 1968). Second, the profound interest in exploring the self may have been increased by individualistic child-rearing patterns.

\section{Conclusion}

Two crucial developments seem to have made self-knowledge into a problem. The first was coming to regard the self as something separate from, and sometimes expressed by, its manifestations in visible action; this appears to have occurred during the early modern period. The second was the increasing motivation to deceive oneself, especially among the Puritans and Victorians, combined with the concomitant recognition that the preva- lence of self-deception rendered all self-knowledge suspect and unreliable.

\section{Potential and Fulfillment}

Maslow (1968) has emphasized the central importance of fulfillment (self-actualization) for understanding the self. His general scheme was derived from the work of Heidegger (1927), according to whom the present self has a number of potentialities for future being; some of these become fulfilled whereas others do not. The guiding concept of potential fulfillment gives meaning and purpose to the present self. Some empirical confirmation of the importance of these relationships, at least for male adults, was provided by Levinson, Darrow, Klein, Levinson, and McKee (1978).

Three types of problems are associated with poteritial and fulfillment. One is how to form a specific concept of one's potential, toward which one may strive. The second is how to fulfill that potential. The third is how to tolerate the frustration and disappointment associated with nonfulfillment, which is inevitable to some degree (cf. May, Angel, \& Ellenberger, 1958, again on the basis of Heidegger, 1927).

\section{Review of Research}

Each of the three problems of potential and fulfillment has been raised by historical developments. Medieval Christianity had solved them all. The guiding concept of human potential fulfillment was the same for all medieval persons: salvation in heaven. The technique was at first a simple matter of participation in church ritual or, preferably, in manastic asceticism. The later Middle Ages increasingly emphasized virtue and piety in one's personal behavior as the means of being judged worthy of eternal salvation. Still, there were clear guidelines for working toward salvation. Although Morris (1972) noted that 12 th century monastics debated the proper forms of monastic life, such debates do not denote a lack of techniques but, rather, a surplus of ideas for the details of technique. Finally, the problem of nonfulfillment was deflected because fulfillment was postponed until after death. Frustration and nonfulfillment during life were therefore to be expected but not to be taken too seriously.

The Christian solution to the questions of human potential and fulfillment undoubtedly dominated medieval life and thought (e.g., Bellah, 1964; Huizinga, 1924/1954), but there may have been some concern with this-worldly fulfillment. Chivalry was the main such ideal pertaining to earthly life (e.g., Hanning, 1977; Tuchman, 1978). Chivalry had two components: honor (deriving from martial prowess) and love. To some extent, of course, these were subsumed under Christianity. The Crusades, for example, epitomized the achievement of salvation by means of fighting. (Indeed, Tuchman has recorded how Popes would absolve embarking crusaders in advance for all atrocities.)

The importance of love as a means of personal fulfillment in medieval life is difficult to gauge. Hanning (1977) discussed the portrayal of courtly love in 12th century literature. Fiedler (1966/1982), however, observed that most medieval portrayals of love were peripheral to the dramatic themes, except for a few great stories of adultery, which typically idealized an impossible love (e.g., Lancelot and Guinevere, or Tristan and Isolde). Stone 
(1977) has argued that hard life, arranged marriage, poor health, and lack of opportunity meant that the experience of passionate love was a rarity for all but the privileged members of a few royal courts, even after the Middle Ages ended. On the other hand, Hunt (1970) has asserted that the system of arranged marriages did have to contend with preferences and inclinations of the young persons (although the existence of preferences still does not necessarily mean passionate love). My inference is that medieval persons did occasionally feel passionate attractions to each other, and there was some limited recognition of passionate love as a powerful state, but it did not have a central place in medieval life. Indeed, and of special importance for the discussion of human goals of fulfillment, persons who were not in love did not usually wish to be in love. Stone (1977) recorded that even in early modern England the person in love was regarded with condescension and sometimes derision by the rest of society. Passionate love, thus, was not idealized as a necessary ingredient for a fulfilled life, unlike today.

During the early modern period, a new interest in late childhood was characterized by the attitude that children were unformed creatures who might turn out good or bad, depending on guidance (Aries, 1962). This view seems to emphasize the potentiality inherent in the child. The solicitous interest in the child's development first received a moral focus, and educational practices emphasized instilling virtue in children. The means were often brutal; for example, Stone (1977) said that the beating of British schoolboys reached an all-time high during this period. For the present discussion, the important point is the heightened belief in the human possibility for growth and change. This belief in potential and development outlasted the religious, moral context in which it was first applied.

MacIntyre (1981) has provided a powerful analysis of how the understanding of human potential deteriorated into chaos during the 18 th century. $\mathrm{He}$ emphasized that the traditional view of morality was as a set of rules and techniques for enabling the person to fulfill his or her (functional) potential. In his view, the traditional moral scheme had three elements: "untutored human nature, man-as-he-could-be-if-he-realized-histelos, and the moral precepts which enable him to pass from the one state to the other" $(1981$, p. 52$)$. The second element was lost, according to MacIntyre, when Christianity (along with its Aristotelian embellishments) lost its hold on society. This occurred throughout the early modern period (Auerbach, 1946/ 1974). The intellectuals rejected Christian thought (or, to keep their jobs, gave it ambiguous and evasive lip service; see Hegel, $1829 / 1966$, for a famous example), and the common people ceased to use their Christian faith as the central or guiding imagery for understanding their lives (e.g., Fiedler, 1966/1982). MacIntyre went on to say that this development converted morality from being a set of rules for achieving fulfillment of one's (potential) true nature to being just a set of rules with neither divine legitimation nor teleological basis. The attempt to explain why anyone should follow such rules was the "quixotic and impossible" task embraced by the moral philosophers of that era, according to MacIntyre. For the present discussion, the key point is that the main means of achieving fulfillment, and the main concept of it, were discredited.

Macintyre continued that the demise of traditional Christian morality, as understood by medievals, entailed the demise of the view that a person was inevitably and essentially required to discharge the obligations of the rank and station to which that person was born. The blacksmith's son, for example, was no longer ineluctably and essentially tied to a moral duty to become a loyal and pious blacksmith himself; and even if he did become one, he was a person first and a blacksmith second, to put it crudely. In Maclntyre's words, starting in the 18th century "man is thought of as an individual prior to and apart from all roles" (1981, p. 56). Persons thus may be permitted to choose their own forms of potential to try to fulfill, instead of just accepting what society assigned them. A person's potential was thus an open question, not a fixed and known matter. Clearly, this development also contributed to making human potential problematic.

The Romantic era is perhaps best known for its quests to replace Christian salvation with viable, secular images of human fulfillment in life on earth. Their efforts focused on work, especially creative art, and inner passion, especially love. These two were not completely separate, of course. The amorous exploits and themes of some Romantic poets are well known, and Altick (1965) noted that the heightened biographical interest in artists' lives during the early 19th century arose from the common belief that artists lived rich inner lives.

The Romantic concepts of human fulfillment in terms of passionate love and creative work, in the context of a rich inner life, deserve further comment because they continue to be our clearest concepts of human fulfillment today. Indeed, one can question whether the psychological discussions of self-actualization (cf. Maslow, 1968; Rogers, 1961) have added anything to them except, perhaps, psychological health, as in Rogers' "openness to experience" instead of neurotic defensiveness.

\section{Work}

Creative art can only be practiced by a small minority of society. A creatively problem-solving attitude can, however, be applied in many tasks, as Maslow (1968) has pointed out, so work could in principle be a powerful source of fulfillment in modern life. Such an emphasis on work could not be credited to (or blamed on) the Romantics entirely. It was Puritanism (or, more generally, Protestantism) that first treated work as an essential human activity. This emphasis on work was a Puritan doctrine the influence of which far outlasted its religious context (cf. Weintraub's, 1978, discussion of Ben Franklin).

Three developments during the 19 th and 20 th centuries suggest that the possibility of finding fulfillment in work has declined or been lost. First, the relation between producer and customer has become increasingly impersonal (Harris, 1981). Harris has contended that the poor workmanship and uncooperativeness of "service" personnel stems from the apathy engendered by the lack of ongoing social bonds between workers and customers, unlike the bonds that characterize tribal or even small-town societies.

Second, the meaning of success has changed. Lasch (1978) argued that for the early Americans success meant an internal, even spiritual triumph, not a competitive or acquisitive coup. Veblen noted as early as 1899 that "conspicuous consumption" was no longer restricted to the "leisure class." The consumption of quality goods is an indication of well-to-do success, and conspicuousness indicates the public and competitive nature of the ideal success. Lasch asserted flatly that "success in our society 
has to be ratified by publicity" (1978, p. 60). He suggested further that the desire for public recognition has altered from a desire for fame (i.e., respect and recognition for one's accomplishments) to the desire to be a celebrity (i.e., to be known and recognized, especially as a personality). Trilling (1955) made a similar point.

Third, the nature of the work has changed fundamentally, even within a given occupation. Braverman (1974) noted that division of labor has two meanings. Even primitive societies have a social division of labor by which different persons contribute different products and services to the society. However, Braverman argued, only modern society has produced the detail or task division of labor by which each task is subdivided into components that are assigned to different persons. This development, according to Braverman, followed from management's discovery that profits could be greatly increased by application of the theories of Babbage (1832/1963). Babbage observed that if one mechanic built the entire product, he spent much of his time doing simple tasks, but he had to be paid according to a level of skill sufficient to perform the hardest task. By hiring cheap labor to perform the simple parts of the job, the expensive labor of the mechanic could be conserved only for the hard parts, thus realizing substantial savings. However, there is a dramatic but hidden psychological cost in that reorganization of labor, as Braverman explicated with excruciating thoroughness. Everyone's work (including that of the most skilled and expensive mechanics) becomes repetitive and loses its visible identification with the productive process as a whole, as well as with the product. Thus, the opportunities to enjoy and take pride in one's work are degraded. Braverman made clear that this reorganization of work pertains not only to assembly-line manufacturing but to white-collar work as well, with equally pernicious effects (also see Larkin, 1979).

In the wake of such developments, work seems to have undergone a shift from intrinsic to extrinsic motivations. One's potential in work became conceived of in terms of possibilities for advancement, prestige, and payment (salary potential), rather than in terms of intrinsic satisfaction from performing the work activities.

It deserves mention that modern work schedules have increased the amount of leisure time, thereby opening new possibilities for fulfillment. The possibility of creative fulfillment through leisure activities cannot be discounted. Still, a cursory perusal of the most popular leisure activities-probably more time is spent watching television than on all other leisure activities combined-soon discovers that creativity is not an essential or pervasive feature.

\section{Love}

Our modern culture regards passionate love as a central concern and powerful ideal of personal fulfillment. Love has come to be regarded as the primary and often the only proper basis for marriage, contrary to earlier attitudes (cf. Stone's, 1977, extensive discussion of the evolution of criteria for mate choice). And a person who goes through life without love will typically be regarded as unfulfilled.

The main drawback of love as a viable form of fulfillment is the impermanence of passion. Fiedler (1966/1982) observed that although many novels end with marriage and promises of everlasting happiness, no one has been able to make a good novel about a happy marriage. Marital bliss is dull, not passionate, at least to readers of novels. Fiedler's suggestion is consistent with behavioral data indicating that frequency of sexual intercourse diminishes substantially over time, even in happy marriages (e.g., Mann, Berkowitz, Sidman, Starr, \& West, 1974).

Passionate love may be a viable concept of human fulfillment, but it is not one that is conducive to prolonged and stable satisfaction.

\section{Others}

Two speculative comments about new concepts of fulfillment deserve mention. During this past century, interpersonal recognition has come to seem like a fulfilling goal; as personality comes to take precedence over achievement, even the talk-show celebrity sort of recognition becomes desired (Lasch, 1978). Additionally, fulfillment for many seems to be a matter of pleasant sensations. This modern degree of hedonistic self-indulgence may be attributable to the stimulation of appetites through advertising (Potter, 1954) and the decline of the capacity for self-denial owing to indulgent parenting (Wheelis, 1958).

\section{Conclusion}

The current problematic nature of potential and fulfillment seems to have taken shape around the start of the 19th century. The three problems mentioned at the beginning of this section (concepts of fulfillment, methods of fulfillment, and tolerance for nonfulfillment) became acute then. Once the guiding concepts of Christian salvation and heaven lost their dominant appeal, they were replaced by secular concepts of human potential and fulfillment. Self-actualization is an appealing but vague term, reflecting society's desire for (but lack of) such concepts. Love and creative work seem the best recognized images of secular fulfillment, but the opportunities for the latter have been degraded by the changed nature of work.

The rejection of the medieval Christian notion of human fulfillment also entailed that moral, virtuous behavior ceased to be considered as the means of achieving fulfillment, as Macintyre (1981) has described. Since then, the problem of finding methods of reaching fulfillment has not been solved. Love, fortunately, seems to occur spontaneously, so techniques of falling in love are not needed, although some might welcome techniques for prolonging the passion. Other than that, there is substantial uncertainty. The writings about self-actualization cited above seem to have even less to say about the techniques of self-actualization than about its characteristics.

The human willingness to tolerate the frustration and disappointment of felt nonfulfillment also diminished with the rejection of the Christian image of salvation as life's fulfillment, for citizens of the Romantic era began to demand satisfactions in this life instead of the next. (It is entirely plausible that persons can feel unfulfilled and frustrated without having a clear concept of what fulfillment would be.) As a result, people began to view society as oppressive and repressive. This conflict between the individual and society is a major theme of the next section of this article. 


\section{Relation Between Individual and Society}

The medieval person's relation to the community was stable and unproblematic. When the attitudes that sustained this stability were undermined and abandoned, people began to feel that society as a whole was indifferent or even hostile to the individual's best interests. This conflict between individual and society has been viewed in several different ways during the past two centuries.

\section{Review of Research}

The medieval mentality believed the social hierarchy to be fixed and legitimate. Nisbet (1973) recorded that medieval social philosophy was wholly dominated by St. Augustine's explanation that God had assigned each person a fixed place in the community. The community was considered to be as much a stable unity as any living organism is. No person should therefore desire to change his or her station, any more than a finger should wish to be the body's eye (to use Augustine's famous simile). Each link in the "great chain of being" (a common phrase) was important. Nisbet (1973) underscored the perceived stability of the system of social relationships by observing that revolution for the purpose of political reform was unknown in Western history until the 18 th century (also see Burke, 1978, pp. 154-155).

Each person was equated with his or her place in the social hierarchy (see earlier discussion of MacIntyre, 1981). The same sentiment is expressed by the primitive and early civilized equation of death with exile: The person's very being is unthinkable apart from the actual context of social roles assigned to that person by God, society, and family. The lack of any substantial sense of an inner self (e.g., Trilling, 1971) was a further reason why medievals equated the person with the public, visible actions and aspects.

The end of the Middle Ages was marked by increasing social mobility, especially in regard to the growth of a middle class. The social hierarchy ceased to be fixed. The instability increased throughout the early modern period. Commoners even began to gain access to the aristocracy, through intermarriage, although the aristocrats resisted and resented such pretensions (Sennett, 1974; Stone, 1977). It is not surprising that conceptions of individuality became articulate and influential during the early modern period. Separating the person from the fixed place in the social network requires one to think of the person as the basic unit, not the community (cf. MacIntyre, 1981; Weintraub, 1978; also Arendt's, 1951, discussion of Hobbes). The individual's interests could be in conflict with those of society, something that the medieval mind would have denied in principle.

The rupture between the individual and society was more than a conceptual advance of the philosophers. It seems to have had a strong behavioral correlate in the development of privacy. Nowadays, we tend to regard privacy as a fundamental human right and a universal human need. The medieval European, however, apparently got along without privacy; indeed, it may never have occurred to him or her to want it. Aries (1962) asserted that "in fact, until the end of the seventeenth century, nobody was ever left alone." Aries (1962) and Stone (1977) described the architectural innovations of the early modern era as newly conducive to privacy. The desire for and cultivation of privacy reflects an attitude that there is some part of life that does not belong to public society.

The increasing separation of public and private domains of experience was a sort of uneasy truce that laid the foundations for a concept of self as being in conflict with society. Sennett (1974) has advanced the important but controversial thesis that 18 th century citizens valued public life (associated with the higher values of civilization and culture) more highly than private life (associated with natural functions), although that value hierarchy was reversed by the end of the 19 th century.

The transition to the 19 th century was marked by a sharply increased sense of conflict between individuals and society. Indeed, a main theme of 19 th century literature was that of the individual versus society (Anderson, 1971; Pütz, 1979; Sypher, 1962; Trilling, 1950). The increasing assertion of the individual is sometimes associated with the incipient decline in the sense of community (Anderson, 1971). Behaviorally, the individual's repudiation of existing society found expression in the numerous rebellions aimed at political reform (Nisbet, 1973).

An individual can only be in conflict with society as a whole if individuals are understood to exist apart from their social positions (see previous discussion of MacIntyre, 1981; also Weintraub, 1978). That is one reason the appearance of the new concept of individuality coincided with recognition of such conflict. It must be emphasized that the traditional system of social rank and hierarchy, having already lost some of its stability, lost its perceived legitimacy as well. That "all men are created equal," a notion labeled a "self-evident truth" in the revolutionary manifesto of the American colonists (1776), would have been inconceivable to the medieval mentality in the sense the colonists asserted it. The medieval mentality took for granted that the aristocrat was a better person than the peasant and that the inequality was legitimated by divine will.

A second, related reason for the increasing sense of conflict between individual and society presumably had to do with the secularization of concepts of fulfillment. The desire for fulfillment during this life, instead of in heavenly afterlife, must have intensified discontent arising from frustration and nonfulfillment during life. Beginning perhaps with Rousseau and continuing throughout the Romantic period, the forms of society were blamed for personal nonfulfillment. Anderson (1971), for example, summarized a central theme of Hawthorne's novels as follows: "The social conditions deny men the chance to be fully men and women the chance to be fully women" (p. 85). Indeed, promoting the individual against the oppressive encroachments of society was a major concern of writers and thinkers throughout the 19th century. Pütz (1979) listed the "key concepts" of American writers of the previous century as "self-reliance, nonconformity, the rejection of the past, the denial of the imperatives of society . . . radical individualism" (p. 33).

The response to the perception of chronic conflict between individual and society evolved through two overlapping stages during the 19th century. In the first, the Romantic hero struggled with society to win freedom to reach fulfillment. Apparently, life meant life in society; there was no alternative (cf. Anderson, 1971). The individual's sole hope lay in the possibility of improving or transforming social conditions. (Belief in the possibility of achieving fulfillment in an improved society was evident in the numerous utopian experiments and writings of 
the 19 th century.) When the struggle became too much, the Romantic hero simply died, as in the celebrated suicide of Goethe's young Werther.

Toward midcentury, transcendentalism emerged as a dominant theme in American letters. As their name implies, the transcendentalists sought their fulfillment not in everyday social life but in private experience that carried them beyond the oppressive and mundane conditions of society. They kept the Romantic values of personal virtue, resourcefulness, and desire for freedom, but they added a willingness to go it alone. If Emerson was the movement's most respected and articulate thinker and Whitman its most extreme embodiment, Thoreau fulfilled its archetypal ideal most vividly. By cultivating his creativity and understanding while living alone in the woods, he seemed to prove that the way to personal fulfillment led away from life in society.

Transcendentalism did not induce large numbers of people to eschew social life altogether. As the era's acclaim of Emerson suggests, people wanted (or were content with) only limited and occasional transcendence. Society was regarded as sort of a necessary evil. Emerson's solution was to live in society but seek fulfillment in private, personal life. In a sense, this view regarded society as tolerable but not satisfying. It contrasts sharply with the view in early 20 th century literature, which attacked society as not just unsatisfying but intolerable as well.

Other historical evidence confirms the perception of conflict between individual and society and the retreat from public life. By the Victorian era, private life (home and family) became the preeminent value and prized refuge, a haven amidst the threatening uncertainties of public life (Fass, 1977; Houghton, 1957; D. W. Howe, 1976; Sennett, 1974). The family's age-old primary function as an economic unit for managing the business of survival was diminished by urban industrial life and was replaced by the function of providing intimate, emotional relations among the family members (Burgess \& Locke, 1945; Fass, 1977). Sennett (1974) argued that the almost axiomatic emphasis on intimate relationships as necessary for psychological health (e.g., Erikson, 1950; Sullivan, 1953) is a historically relative product of the declining participation in public life.

The Emersonian idea that fulfillment could be obtained in private life, in peaceful coexistence with public society, seems intrinsically plausible, but it vanished abruptly from serious writing at the start of the 20 th century. Alienation became the major theme in literature (Klein, 1964; Pütz, 1979). Specific meanings of alienation vary among different theorists (see, especially, Seeman, 1959), but its general sense in early 20 th century literature may perhaps be expressed as a mixture of powerlessness (futility), meaninglessness (emptiness), and nonfulfillment (frustration).

If one assumes that the literary emphasis on alienation reflected a major aspect of the contemporary collective psyche, it must be inferred that the early 20 th century citizens saw themselves as utterly in the grip of social forces and powers that were indifferent to them personally. This seems entirely plausible from a sociological standpoint. The transition to industrial, urban life for the majority of persons entailed serious economic interdependence. Self-sufficiency was obsolete, and economic depressions (such as occurred in the 1890s and 1930s) threatened personal survival. The individual's utter dependency on society was not yet tempered by government social programs such as welfare and social security nor by corporate guarantees of job security and retirement pensions.

It appears that society was still perceived as a barrier to living meaningful and fulfilled lives, but the chance to escape into private fulfillments apart from society had somehow been lost. In terms of the present discussion of the individual's relation to society, the balance of power in that conflict seems to have shifted heavily in society's favor at the start of this century.

Two other features of early 20 th century writing are consistent with this analysis. First, if the individual was at society's mercy, then the self-respect of the individual would presumably suffer. This seems to have occurred. Whereas the (secular) supreme being of 19th century literature was "the imperial self" (Anderson, 1971), 20th century writers ceased to regard the self as having "ultimate value and substance" (Sypher, 1962). Pütz (1979) and Sypher quoted a line from Musil's novel as representative of the new attitude toward selfhood: "The center of gravity no longer lies in the individual but in the relations between things." Thus, society holds the power, and the individual is reduced to a "mere functionary" (Sypher, 1962). Langbaum (1979) gave a similarly bleak account of the status of the self in 20th century literature, although he saw early signs of the loss of self already in the Victorian poetry of Matthew Arnold. Sypher's thesis of the devaluation of selfhood also meshes with Altick's (1965) discussion of the newly unsympathetic and even iconoclastic trends in biographical writing early in the 20 th century.

Second, if persons feel themselves as society's rather helpless victims, their hostility toward society should increase. Indeed, 20th century writers actively and bitterly chronicled the faults and inadequacies of existing society. The zest to expose and attack social evils became an end in itself, exemplified by muckraking in journalism and in novels such as Sinclair's The Jungle. This hostility toward society contrasts with the apparent passivity of the 19th century authors on social issues (Anderson, 1971; Trilling, 1971).

The degree to which the modern individual is ineluctably immersed in society has prompted some writers to suggest that the chances of achieving true individuality are diminishing, thus reversing the centuries-long trend toward increased individuality (Adorno, 1951; Fromm, 1941/1969; Habermas, 1973/1975; Landmann, 1971). A similar point made by other observers is that personality types have increasingly emphasized conforming to the expectations of others instead of following strictly internal motivations (e.g., Friedenberg, 1959; May, 1953; Riesman, 1950; Wheelis, 1958). Such developments can be attributed to a variety of factors, including economic interdependence, mass-produced goods, the influence of news media and experts who tell persons what to think (e.g., Fromm, 1941/ 1969; Landmann, 1971), the manipulation of desire by advertising (e.g., Henry, 1963; Potter, 1954), and the bureaucratization of work that requires social skills and compatibility with others (e.g., Kett, 1977; Whyte, 1956).

After the Second World War, the postmodern American fiction moved away from the stance of pure rage and rebellion. Alienation was still a theme, but it was no longer the main point. Postmodern fiction showed a new interest in what Klein (1964) calls accommodation, which took the form of alternation between adjusting oneself to fit into society and attempting to assert oneself. Accommodation represented a preference for life 
with compromise over perpetual and futile rebellion. Of course, there were misgivings; to some, accommodation as practiced in the suburbs looked a lot like mere survival by camouflage (Sypher, 1962). It deserves mention that the accommodation movement Klein describes entailed a partial return to accepting society as it is. I. Howe (1959/1969) and Roth (1961/1969) suggested that postmodern writers downplayed social criticism because they found it difficult enough just to understand the new mass society and to portray modern life credibly.

In the literature of the 1960 s, according to Pütz (1979), the "struggle for identity" took the form of myth-making. In mythmaking, the protagonist projects self-made schemes of coherence onto the world. Myth-making is reminiscent of transcendentalism in several ways, most notably the passive acceptance of society's general nature as given and the reliance on internal resources to provide life with coherence (meaning) and fulfillment.

Thus, the recent trends suggest that the individual has accepted the state of being immersed in and dependent on society and is struggling to find meaning and fulfillment within those limitations.

\section{Conclusion}

The relation of the medieval person to his or her society was unproblematic owing to two fundamental, related attitudes. The first was the denial that the person existed apart from his or her position in society. The second was faith that if one fulfilled one's allotted role in society, one's life would have meaning, higher value, and fulfillment, because the social order had its design (and purpose) and legitimacy from God.

The relation of the self to society became a problem when these two basic attitudes were destroyed. The first attitude was undermined by the rise in social mobility, which detached the individual from the social station to which he or she was born, and by the growth of internality. (There may have been additional causes.) The second attitude was undermined as humanity ceased to live by Christian faith and imagery, because the divine legitimacy of the social order was repudiated, and because there was no longer any basis for having faith that fulfillment and reward would be the inevitable result of doing what society bid. The second attitude was also undermined by the fact that society gradually ceased giving each person an unequivocal message about how to live and what to do; liberal reforms presented persons with an increasing array of options. The collapse of these two attitudes, and the resultant problematic nature of the relation between individual and society, were further aggravated by the increasing demand for fulfillment in this life instead of in the next, because society was blamed for the widespread feelings of nonfulfillment.

The problem of the individual's relation to society then evolved through four stages. Believing that society prevented them from reaching fulfillment, individuals first struggled for the freedom to seek fulfillment. Society became more flexible, but in the process it offered even less guidance to individuals as to how to live, and fulfillment did not ensue. Next, individuals tried to seek fulfillment in private, away from society. This might have worked, except that social evolution was linking persons ever closer together (e.g., by communcations media and economic interdependence). Upon discovering that there was
Table 2

Self-Definition Processes

\begin{tabular}{|c|c|c|c|}
\hline Type & Description & Problem & Example \\
\hline I & $\begin{array}{l}\text { Assigned } \\
\text { component }\end{array}$ & None (stable, passive) & $\begin{array}{l}\text { Family lineage, } \\
\text { gender }\end{array}$ \\
\hline II & $\begin{array}{l}\text { Single- } \\
\text { transformation }\end{array}$ & $\begin{array}{l}\text { Achievement; single self- } \\
\text { definition by one } \\
\text { standard }\end{array}$ & $\begin{array}{l}\text { Motherhood, } \\
\text { knighthood }\end{array}$ \\
\hline III & $\begin{array}{l}\text { Hierarchy of } \\
\text { criteria }\end{array}$ & $\begin{array}{l}\text { Achievement: frequent or } \\
\text { continual redefinition of } \\
\text { self by one standard }\end{array}$ & $\begin{array}{l}\text { Wealth (in } \\
\text { middle class) }\end{array}$ \\
\hline IV & Optional choice & $\begin{array}{l}\text { Choice is available: } \\
\text { Alternative options } \\
\text { exist, but one option is } \\
\text { dominant or clear } \\
\text { guidelines exist }\end{array}$ & $\begin{array}{l}\text { Religious or } \\
\text { political } \\
\text { affiliation (in } \\
\text { pluralistic } \\
\text { society) }\end{array}$ \\
\hline $\mathrm{v}$ & Required choice & $\begin{array}{l}\text { Person is required to find } \\
\text { metacriteria for } \\
\text { choosing among } \\
\text { incompatible } \\
\text { alternatives }\end{array}$ & $\begin{array}{l}\text { Choice of mate } \\
\text { or career (in } \\
\text { modern } \\
\text { society) }\end{array}$ \\
\hline
\end{tabular}

no escape from society, individuals recognized themselves as helpless (powerless) and still unfulfilled; this was the stage of alienation and bitter social criticism. Finally, individuals began to accept that society neither permitted escape nor promised fulfillment, and they began to seek ways of actively and creatively seeking fulfillment as individuals in the midst of society. This is the current form of the problem.

\section{Self-Definition Processes}

If identity is regarded as a theory or concept synthesized from knowledge about the self (cf. Epstein, 1973; Schlenker \& Leary, 1982), its creation must be regarded as a process of definition. Different features of the self are defined in different ways. Before proceeding to a discussion of the historical shifts in selfdefinition processes, it is necessary to describe those processes.

There appear to be three main types of self-definition processes. Components of self-definition can be acquired by being assigned to the individual, they can be acquired by achievement, or they can be acquired by acts of choice. Achievement and choice processes can be subdivided further, creating five types of self-definition processes in all. These are summarized in Table 2.

Type I refers to assigned components of self. These are relatively stable and unproblematic. Family lineage and gender are clear examples of this type. Type II refers to single-transformation achievement; that is, one decisive achievement or event, such as giving birth to a child or becoming a tribal chief, defines this component of the self. Once acquired, transformational components are stable and unproblematic, which is what distinguishes them from Type III components. Type III (hierarchical) components are permanently and more or less continuously subject to redefinition. Self-definition by wealth is a paradigmatic example, for one's wealth is continually subject to further increase (or loss). Self-definition by a hierarchical process thus works on a hierarchy of criteria. It is problematic in 
the sense that it is always in flux, so one has to keep proving oneself, but it is unproblematic in that the criteria (and often the procedures) for self-definition are clear and well defined.

Hierarchical self-definition processes confront individuals with a standard and define them according to how well they measure up. When the individual is confronted with not one but several such standards, and the behaviors for conforming to them are not mutually compatible, choice is required. I distinguish two types of self-definition-by-choice according to the existence of a guiding system of values for choice, which could also be stated as a matter of whether choice is required or merely available. If such a firm set of values exists, the individual can conform to it, unless he or she feels strongly enough about some other alternative to betray the general values. In such cases (Type IV), the person may choose but is not compelled to do so. Type $\mathrm{V}$ cases, in contrast, confront the individual with choices but do so in the absence of any ultimate or general (single) set of values that can serve as a guideline. In such circumstances, the individual must make choices. It is obvious that Type V selfdefinition is highly problematic.

\section{Review of Research}

Medieval identity was mainly defined by passive-stable and transformational (Type I and II) processes. The person was defined by the social rank and kinship network into which he or she was born. Gender decisively determined the course of one's life. Well-defined transitions marked the acquisition of new identity components such as becoming an adult, marriage, parenthood, and succession to new roles or titles because of the death of the incumbent.

Some traces of hierarchical (Type III) and perhaps even optional-choice (Type IV) processes can be observed in medieval society, but these were probably exceptional. The concern with honor, glory, virtue, and morality reflected that the self could be redefined at times. In particular, gaining glory through feats of arms was in a sense hierarchical and competitive, although there was no clear standard of measurement. Morris (1972) suggested that some men had to choose between different occupations or between different forms of monastic life. Given that these choices were within the general context of Christian faith and values, they would seem to denote optional-choice processes. However, the prevalence of such processes in medieval life may well have been quite limited. In general, medieval selfdefinition was accomplished primarily by the simplest and least problematic types (I and II) of processes.

In the early modern period, self-definition became centrally concerned with the problems characteristic of hierarchical (Type III) and optional-choice (Type IV) processes. The rise of the middle class entailed an increased use of wealth as a standard of self-definition, with its attendant issues of competition, uncertainty, constant change, and discontent. Indeed, toward the end of this era wealth began to replace lineage as the defining standard of social status, which caused even the aristocracy to become concerned with wealth as a factor in self-definition (cf. Stone, 1977; also Sennett, 1974).

The Protestant schism, and then the subsequent decline of Christian faith, were the eras in which optional-choice processes were most widespread. Protestantism confronted persons with an alternative to their most fundamental beliefs. Christian faith had always served as the ultimate arbiter of questions about proper and correct action. Now that there were rival forms of Christian creed, a new criterion was needed to decide whether Protestantism or Catholicism was the true religion, but obviously there was no such criterion. To say that the schism forced individuals to make choices seems misleading, however, because most individuals were brought up in one or the other faith. They could repudiate it (i.e., make their own choice), but they could also remain foreclosed in the faith of their upbringing. The Protestant schism was therefore conducive to Type IV self-definition because it made personal choice possible but not obligatory. In the same way, the decline of Christian faith made its rejection an option for individuals, but they did not have to confront that choice; they could adhere to it in a foreclosed fashion.

I do not wish to give the impression that choice inevitably meant repudiation of the faith by which one had been brought up. One could certainly confront the alternatives and make a decisive personal choice in favor of that faith. My point is just that making such a choice is a self-definitional act quite different from the adherence to such faith without ever questioning it. The difference lies in the problematic and difficult nature of the process of self-definition that is involved.

The decline of Christian faith continued during the Romantic era. It is important to emphasize that most persons still professed belief in Christianity, but their belief became less and less influential over their daily lives. More generally, the Romantics believed that there were ultimate values, whatever they might be, but increasingly recognized the necessity for the individual to make choices for the sake of self-definition. The Romantic attitude toward society (discussed in the previous section of this article) reflects the optional-choice process. Society was perceived as oppressive, and a need to reject some of society's dictates was recognized; but these acts still took place within an overarching scheme of belief, faith, and value.

It is worth adding that socioeconomic developments contributed to the proliferation of options and thus to Type IV selfdefinition. Society became more flexible, first through the decline of the rigid feudal system of social roles, then through the rapid growth of urban and industrial job opportunities, and finally through political reform and revolution that enhanced individual liberties. As a result, individuals (at least white men) often had a variety of alternative options for how to live their lives. The farmer's son who forsook farming and moved to the city to take a factory job furnishes a paradigmatic example of the exercise of an optional-choice self-definition process, with respect to occupation, made viable by these social changes.

During the Victorian era, increasing numbers of people began to recognize themselves as not believing in Christianity. Meyer (1976) says that a fundamental concern during the Victorian era was whether morality could survive without religion, which suggests that the failure of basic values was experienced as critical. Without such a framework of basic values, choice is highly problematic, for individuals are forced to choose yet no guidelines or criteria for choosing are available. That such choice was increasingly experienced to be so problematic is attested by the increasing artistic and philosophical concern with choice early in the 20th century, such as reflected in the existentialist concern with authenticity and responsibility (cf. Sypher, 
1962; Trilling, 1971). It is also attested by the newly problematic nature of adolescence, which deserves special comment.

The years following puberty have been recognized as turbulent and trouble-prone for a long time (Greven, 1977; Kett, 1977; Stone, 1977). However, the problematic nature of adolescence changed and intensified late in the 19th century (Baumeister \& Tice, 1986; Demos \& Demos, 1969; Kett, 1977; Larkin, 1979; Stone, 1977). The idea that the problems of adolescence changed toward greater prevalence and complexity is further supported by the observation that novels specifically concerned with adolescence first appeared in abundance around the turn of the 20th century (Kiell, 1959; Pütz, 1979). Although space precludes thorough analysis of this alteration of adolescence, it seems quite likely that part of the problem arose from social changes that left crucial aspects of self-definition, especially selection of spouse and career, up to the adolescent. Victorian adolescents thus had to define their adult identities by making choices without clear or specific guidelines and amid a general upheaval of cultural values. Such choices reflect required-choice (Type V) self-definition, which is clearly the most difficult and problematic. These difficulties of self-definition, originating in the Victorian era, have become widespread during the 20th century, although they have been periodically obscured by the exigencies of war and other calamities. The adolescent struggle with required-choice self-definition has been recognized as a normative feature of human development and labeled identity crisis (e.g., Erikson, 1968). Moreover, modern self-definition by career is doubly problematic, requiring first a Type V choice and then Type III achievement by hierarchical standard, as when the decision to go into some business is followed by years of struggle to climb the corporate ladder of promotions. Type IV problems also follow the making of commitments in Type $V$ choice, for persons tend to feel that they could reject and alter their commitments (as in divorce and in career change) once they have been made (cf. Levinson et al., 1978).

\section{Conclusion}

The modern problems with self-definition can be understood as resulting from a shift in types of self-definition processes. Medieval identity was mainly defined by the relatively simple and straightforward processes (Types I and II), which bestowed identity owing to birth or to single-event achievements. These aspects of the self would often remain the same for life. Modern identity, in contrast, depends on the problematic and unstable self-definition processes (Type V, often followed by Types III and IV) for some of its central components. In the absence of consensual, unimpeachable guidelines (values) that are adequate for making the choices that define the self, these guidelines are presumed to exist hidden within the self. Self-definition often has to establish such inner criteria, either by finding them or by inventing them.

\section{Discussion}

I have attempted to describe the historical evolution of four problem areas regarding the self. It remains to describe briefly how current psychological research addresses those problems.

\section{Self-Knowledge}

Self-knowledge seems to have become problematic because of the increasing use of concepts of an inner, hidden self, and because of increasing recognition of self-deception.

The question of the extent of self-knowledge has recently been formulated in terms of persons' awareness of their internal states and mental processes (Nisbett \& Wilson, 1977; Smith \& Miller, 1978). The idea that persons are unaware of the true causes of their behavior has been put forward in a different way by Langer (1978), and Bem (1972) has also argued that selfperception has innate limitations. The topic of self-deception has received the attention of psychological theory, stimulated partly by attempts to interpret Freud's theory of defense mechanisms in terms of self-deception (Hilgard, 1949; Sartre, 1953). Empirical and even experimental work has focused directly on self-deception (Gur \& Sackeim, 1979; Sackeim \& Gur, 1979). Self-deception was implicit in studies of some attributional biases (e.g., Beckman, 1970; Shaver, 1970), and although there is evidence that some such biases were mediated by a motivation to impress others (Weary, 1980), self-deception is still implicated to some extent (Greenberg, Pyszczynski, \& Solomon, 1982). Evidence that depressed people are less prone than nondepressed people to show those attributional biases sheds important light on individual differences in self-deception (e.g., Alloy \& Abramson, 1979; Lewinsohn, Mischel, Chaplin, \& Barton, 1980). Greenwald (1980) provided a general discussion of how unwitting but motivated fabrication of personal history distorts self-knowledge, such as by retrospective distortion of the self's abilities or opinions (e.g., Baumeister \& Covington, 1985; Bem \& McConnell, 1970; Conway \& Ross, 1984). Hogan (1983) has observed that the current research on self-handicapping (Berglas \& Jones, 1978; E. E. Jones \& Berglas, 1978) provides further insight into modes, motives, and processes of selfdeception.

Research has also begun to explore how self-knowledge is organized (Markus, 1977; and much subsequent work). That different experiences can shape or alter the self-concept has recently been suggested by E. E. Jones, Rhodewalt, Berglas, \& Skelton (1981) in their biased scanning theory of self-knowledge. Moreover, self-knowledge is not equally problematic for all persons or for the same person at all times. The causes and consequences of differences in the degree to which individuals pay attention to themselves has received increasing attention in recent years (e.g., Carver, 1979; Carver \& Scheier, 1981; Duval \& Wicklund, 1972; Fenigstein, Scheier, \& Buss, 1975; Hull \& Levy, 1979; Wicklund, 1975).

\section{Fulfillment}

I listed three problems pertaining to human potential and fulfillment, namely the formation of a concept of potential, techniques for attaining fulfillment, and coping with nonfulfillment. The development of concepts of human potential was one of the original, fundamental concerns of humanistic psychology. Individual potential is implicit in Markus and Nurius's (in press) study of possible selves, and the goal-directed nature of selfhood has been operationalized in research on symbolic self-completion (Wicklund \& Gollwitzer, 1981, 1982). The issues of technique, in contrast to those of the concept of poten- 
tial, are relatively unstudied. One could interpret studies of worker satisfaction as dealing with techniques of fulfillment, but this seems to be stretching the point. Some research into meditation (e.g., Tart, 1969), and drug use (Klavetter \& Mogar, 1967; Mogar, 1965; see Baumeister \& Placidi, 1983) have conceived these as techniques for seeking fulfillment. As for nonfulfillment, one again must stretch to interpret the vast bulk of studies of frustration as if they dealt with nonfulfillment of human potential. Still, Wicklund and Gollwitzer's work (1981) deals with responses to experiences of nonfulfillment, and research on mid-life crises (Levinson et al., 1978) has recognized nonfulfillment of one's potential as a central determinant of such crises.

\section{Relation of Individual to Society}

I suggested that the problematic nature of the individual's relation to society stemmed from being inextricably bound up in interpersonal society but needing to define one's own meaning and purpose in life actively, because society no longer provides the individual with these. The current issue in this problem area seems to be the extent to which the self is inextricably linked with how it is perceived by other persons. Research on self-presentation has demonstrated numerous ways in which behavior is subtly motivated by an overriding concern with how one is perceived by others (cf. Baumeister, 1982; Schlenker, 1980; Tedeschi, 1981). Some work has shown how features of the inner self derive from the public, visible behaviors (e.g., Baumeister, 1986; Baumeister \& Cooper, 1981; E. E. Jones et al., 1981; Kenrick, Baumann, \& Cialdini, 1979).

Self-presentation is, of course, not the only research area that deals with the relation of the individual to society. Research on conformity and on socialization also deals essentially with the same relation. The self-presentation work, however, deals most directly with how the problematic nature of selfhood derives from that relation.

\section{Self-Definition}

Self-definition processes seem less amenable to the prevailing research methods than are the other problem areas I have discussed. Still, there has been some work. I suggested that the central problem of self-definition processes was in the type of such processes that have come to be prevalent; specifically, choice in the absence of certain guidelines, followed by continual redefinition of self on hierarchical standards, has entailed that selfdefinition be complex, difficult, and uncertain. Insofar as adolescence is a focus for the struggle with such self-definition processes, research on adolescent identity crises (e.g., Erikson, 1968; Marcia, 1966, 1967; Orlofsky, 1978; Orlofsky, Marcia, \& Lesser, 1973; for reviews see Baumeister, Shapiro, \& Tice, 1985; Bernard, 1981; or Bourne, 1978) is centrally concerned with this problematic nature of self-definition.

For each of the four problem areas, the recognition of the problem is historically relative. To some degree, also, the phenomena in question are also historically relative. It is my hope that an awareness of historical variation relative to these issues of selfhood will provide a context that will facilitate the study and understanding of these problems.

\section{References}

Adorno, T. (1951). Minima moralia [Reflections on damaged life] (E Jephcott, Trans.). Frankfurt. West Germany: SuhrKamp.

Alloy, L. B., \& Abramson, L. Y. (1979). Judgment of contingency in depressed and nondepressed students: Sadder but wiser? Journal of Experimental Psychology: General, 108, 441-485.

Altick, R. (1965). Lives and letters: A history of literary biography in England and America. New York: Knopf.

Anderson, Q. (1971). The imperial self. New York: Knopf.

Arendt, H. (1951). The origins of totalitarianism. New York: Harcourt Brace Jovanovich.

Aries, P. (1962). Centuries of childhood: A social history of family life (R. Baldick, Trans.). New York: Random House.

Aries, P. (1981). The hour of our death (H. Weaver, Trans.). New York: Knopf.

Auerbach, E. (1974). Mimesis: The representation of reality in Western literature (W. Trask, Trans.). Princeton, NJ: Princeton University Press. (Original work published 1946)

Babbage, C. (1963). On the economy of machinery and manufactures. New York. (Original work published 18.32)

Baumeister, R. F. (1982). A self-presentational view of social phenomena. Psychological Bulletin, 91, 3-26.

Baumeister, R. F. (1986). Public self and private self. New York: Springer-Verlag.

Baumeister, R. F., \& Cooper, J. (1981). Can the public expectation of emotion cause that emotion? Journal of Personality, 49, 49-59.

Baumeister, R. F., \& Covington, M. V. (1985). Self-esteem, persuasion, and retrospective distortion of initial attitudes. Electronic Social Psychology, 1,8501014.

Baumeister, R. F., \& Placidi, K. S. (1983). A social history and analysis of the LSD controversy. Journal of Humanistic Psychology, 23(4), $25-$ 58.

Baumeister, R. F., Shapiro, J. P., \& Tice, D. M. (1985). Two kinds of identity crisis. Journal of Personality, 53, 407-424.

Baumeister, R. F., \& Tice, D. M. (1985). Self-esteem and responses to success and failure: Subsequent performance and intrinsic motivation. Journal of Personality, 53, 450-467.

Baumeister, R. F., \& Tice, D. M. (1986). How adolescence became the struggle for self: A historical transformation of psychological development. In J. Suls \& A. G. Greenwald (Eds.), Psychological perspectives on the self (Vol. 3, pp. 183-201). Hilisdale, NJ: Erlbaum.

Beckman, L. (1970). Effects of students' performance on teachers' and observers' attributions of causality. Journal of Educational Psychology, 61, 76-82.

Bellah, R. N. (1964). Religious evolution. American Sociological Review, 29, 358-374.

Bem, D. J. (1972). Self-perception theory. In L. Berkowitz (Ed.), Advances in experimental social psychology (Vol. 6, pp. 1-62). New York: Academic Press.

Bem, D. J., \& McConnell, H. K. (1970). Testing the self-perception explanation of dissonance phenomena: On the salience of premanipulation attitudes. Journal of Personality and Social Psychology, 14, 2331.

Berglas, S. C., \& Jones, E. E. (1978). Drug choice as a self-handicapping strategy in response to noncontingent success. Journal of Personality and Social Psychology; 36, 405-417

Bernard, H. S. (1981). Identity formation during late adolescence: A review of some empirical findings. Adolescence, 16, 349-357.

Bourne, E. (1978). The state of research on ego identity: A review and appraisal. Journal of Youth and Adolescence, 7, 371-392.

Braverman, H. (1974). Labor and monopoly capital: The degradation of work in the twentieth century. New York: Monthly Review Press.

Burgess, E. W., \& Locke, H. J. (1945). The family: From institution to companionship. New York: American Book. 
Burke, P. (1978). Popular culture in early modern Europe. New York: Harper \& Row.

Carver, C. S. (1979). A cybernetic model of self-attention processes. Journal of Personality and Social Psycholog:: 37, 1251-1281.

Carver, C. S., \& Scheier, M. (1981). Attention and self-regulation: $A$ control-theory approach to human behavior. New York: Springer-Verlag.

Conway, M., \& Ross, M. (1984). Getting what you want by revising what you had. Journal of Personality and Social Psychology, 47, 738748.

Demos, J., \& Demos, V. (1969). Adolescence in historical perspective. Journal of Marriage and the Family, 31, 632-638.

Duval, S., \& Wicklund, R. A. (1972). A theory of objective self-awareness. New York: Academic Press.

Epstein, S. (1973). The self-concept revisited: Or a theory of a theory. American Psychologist, 28, 404-416.

Erikson, E. H. (1950). Childhood and society. New York: Norton.

Erikson, E. H. (1968). Identity: Youth and crisis. New York: Norton.

Fass, P. (1977). The damned and the beautiful: American youth in the 1920s. New York: Oxford University Press.

Fenigstein, A., Scheier, M. F., \& Buss, A. H. (1975). Public and private self-consciousness: Assessment and theory. Jourmal of Consulting and Clinical Psychology, 43, 522-527.

Fiedler, L. A. (1982). Love and death in the American novel. New York: Stein and Day. (Original work published 1966)

Freud, S. (1959). Fragment of an analysis of a case of hysteria. In A. Strachey \& J. Strachey (Eds. and Trans.), Collected papers (Vol. 3, pp. 13-136). New York: Basic Books. (Original work published 1905)

Friedenberg, E. Z. (1959). The vanishing adolescent. Boston: Beacon Press.

Fromm, E. (1969). Escape from freedom. New York: Holt, Rinehart \& Winston. (Original work published 1941)

Gergen, K. J. (1971). The concept of self. New York: Holt, Rinehart \& Winston.

Greenberg, J., Pyszczynski, T., \& Solomon, S. (1982). The self-serving attributional bias: Beyond self-presentation. Journal of Experimental Social Psychology, 18, 56-67.

Greenwald, A. G. (1980). The totalitarian ego: Fabrication and revision of personal history. American Psychologist, 35, 603-618.

Greven, P. (1977). The Protestant temperament. New York: Knopf.

Gur, R. C., \& Sackeim, H. A. (1979). Self-deception: A concept in search of a phenomenon. Journal of Personality and Social Psychology, 37, 147-169.

Habermas, J. (1975). Legitimation crisis (T. McCarthy, Trans.). Boston: Beacon Press. (Original work published 1973)

Hanning, R. W. (1977). The individual in twelfth-century romance. New Haven, CT: Yale University Press.

Harris, M. (1981). America now: The anthropology of a changing culture. New York: Simon \& Schuster.

Hegel, B. W. F. (1966). Vorlesungen ueber die Beweise vom Dasein Gottes [Lectures on the proofs of God's existence]. Hamburg, West Germany: Felix Meiner Verlag. (Original work published 1829)

Heidegger, M. (1927). Sein und Zeit [Being and time]. Tuebingen, West Germany: Niemeyer.

Henry, J. (1963). Culture against man. New York: Random House.

Hilgard, E. R. (1949). Human motives and the concept of self. American Psychologist, 4, 374-382.

Hogan, R. (1983). On publishing in personality psychology: Trends and developments. Personality Forum, 1, 4-5.

Houghton, W. E. (1957). The Victorian frame of mind: 1830-1870. New Haven, CT: Yale University Press.

Howe, D. W. (1976). Victorian culture in America. In D. Howe (Ed.), Victorian America (pp. 3-28). Philadelphia: University of Pennsylvania Press.

Howe, I. (1969). Mass society and post-modern fiction. In M. Klein (Ed.), The American novel since World War II. New York: Fawcett. (Original work published 1959)
Huizinga, J. (1954). The waning of the Middle Ages. Garden City, NY: Doubleday. (Original work published 1924)

Hull, J. G., \& Levy, A. S. (1979). The organizational functions of the self: An alternative to the Duval and Wicklund model of self-awareness. Journal of Personality and Social Psychology, 37, 756-768.

Hunt, D. (1970). Parents and children in history. New York: Harper \& Row.

Jones, E. E., \& Berglas, S. C. (1978). Control of attributions about the self through self-handicapping strategies: The appeal of alcohol and the role of underachievement. Personality and Social Psychology Bulletin, 4, 200-206.

Jones, E. E., Rhodewalt, F., Berglas, S., \& Skelton, J. A. (1981). Effects of strategic self-presentation on subsequent self-esteem. Journal of Personality and Social Psychology, 41, 407-421.

Jones, S. C. (1973). Self- and interpersonal evaluations: Esteem theories versus consistency theories. Psychological Bulletin, 79, 185-199.

Jung, C. G. (1971). The spiritual problem of modern man. In J. Campbell (Ed.), The portable Jung. New York: Viking. (Original work published 1928)

Kenrick, D., Baumann, D., \& Cialdini, R. B. (1979). A step in the socialization of altruism as hedonism: Effects of negative mood on children's generosity under public and private conditions. Journal of Personality and Social Psychology, 37, 747-755.

Kett, J. F. (1977). Rites of passage: Adolescence in America 1790 to the present. New York: Basic Books.

Kiell, N. (1959). The adolescent through fiction: A psychological approach. New York: International Universities Press.

Klavetter, R., \& Mogar, R. (1967). Peak experiences: Investigation of their relationship to psychedelic therapy. Journal of Humanistic Psychology, 7. 171-177.

Klein, M. (1964). After alienation: American novels in mid-century. Freeport, NY: Books for Libraries Press.

Landmann, M. (1971). Das Ende des Individuums [The end of individuality]. Stuttgart, West Germany: Klett.

Langbaum, R. (1979). The mysteries of identity: A theme in modern literature. New York: Oxford University Press.

Langer, E. J. (1978). Rethinking the role of thought in social interaction. In J. Harvey, W. Ickes, \& R. Kidd (Eds.), New directions in attribution research (Vol. 2, pp. 35-58). Potomac, MD: Erlbaum.

Larkin, R. W. (1979). Suburban youth in cultural crisis. New York: Oxford University Press.

Lasch, C. (1978). The culture of narcissism. New York: Norton.

Levinson, D. J., Darrow, C. N., Klein, E. B., Levinson, M. H., \& McKee, B. (1978). The seasons of a man's life. New York: Ballantine.

Lewinsohn, P. M., Mischel, W., Chaplin, W., \& Barton, R. (1980). Social competence and depression: The role of illusory self-perceptions. Journal of Abnormal Psychology, 89, 203-212.

MacIntyre, A. (1981). After virtue. Notre Dame, IN: University of Notre Dame Press.

Mann, J., Berkowitz, L., Sidman, J., Starr. S., \& West, S. (1974). Satiation of the transient stimulating effect of erotic films. Journal of Personality and Social Psychology, 30, 729-735.

Marcia, J. E. (1966). Development and validation of ego-identity status. Journal of Personality and Social Psychology, 3, 551-558.

Marcia, J. E. (1967). Ego identity status: Relationship to changes in selfesteem, "general maladjustment" and authoritarianism. Journal of Personality, 35, 118-133.

Markus, H. (1977). Self-schemata and processing information about the self. Journal of Personality and Social Psychology. 35, 63-78.

Markus, H., \& Nurius, P. (in press). Possible setves. American Psychologist.

Markus, H., \& Smith, J. (1981). The influence of self-schemata on the perception of others. In N. Carter \& J. Kihlstron (Eds.), Personality, cognition, and social interaction (pp 233-262). Hillsdale, NJ: Erlbaum. 
Maslow, A. H. (1968). Toward a psychology of being. New York: Van Nostrand.

May, R. (1953). Man's search for himself. New York: Dell.

May, R., Angel, E., \& Ellenberger, H. F. (1958). Existence. New York: Simon \& Schuster.

Meyer, D. H. (1976). American intellectuals and the Victorian crisis of faith. In D. W. Howe (Ed.), Victorian American (pp 59-77). Philadelphia: University of Pennsylvania Press.

Mogar, R. (1965). Current status and future trends in psychedelic (LSD) research. Journal of Humanistic Psychology, 5, 147-166.

Morris, C. (1972). The discovery of the individual: 1050-1200. New York: Harper \& Row.

Nisbet, R. (1973). The social philosophers: Community and conflict in Western thought. New York: Crowell.

Nisbett, R. E., \& Wilson, T. D. (1977). Telling more than we can know: Verbal reports on mental processes. Psychological Review, 84, 231259.

Orlofsky, J. L. (1978). Identity formation, $n$ achievement and fear of success in college men and women. Journal of Youth and Adolescence, 7, 49-62.

Orlofsky, J. L., Marcia, J. E., \& Lesser, I. M. (1973). Ego identity status and the intimacy versus isolation crisis of young adulthood. Journal of Personality and Social Psychology, 27, 211-219.

Potter, D. M. (1954). People of plenty. Chicago: University of Chicago Press.

Pütz, M. (1979). The story of identity: American fiction of the sixties. Stuttgart, West Germany: Metzler.

Rieff, R. (1968). The triumph of the therapeutic. New York: Harper.

Riesman, D. (1950). The lonely crowd. New Haven, CT: Yale University Press.

Rogers, C. R. (1961). On becoming a person. Boston: Houghton Mifflin.

Roth, P. (1969). Writing American fiction. In M. Klein (Ed.), The American novel since World War II. New York: Fawcett. (Original work published 1961)

Sackeim, H. A., \& Gur, R. C. (1979). Self-deception, other-deception, and self-reported psychopathology. Journal of Consulting and Clinical Psychology, 47, 213-215.

Sartre, J. P. (1953). Existential psychoanalysis (H. Barnes, Trans.). Chicago: Regnery.

Schlenker, B. (1980). Impression management: The self-concept, social identity, and interpersonal relations. Monterey, CA: Brooks/Cole.

Schlenker, B. R., \& Leary, M. R. (1982). Social anxiety and self-presentation: A conceptualization and model. Psychological Bulletin, 92, 641-669.

Seeman, M. (1959). On the meaning of alienation. American Sociological Review, 24, 782-791.

Sennett, R. (1974). The fall of public man. New York: Random House.

Shaver, K. G. (1970). Defensive attribution: Effects of severity and rele- vance on the responsibility assigned for an accident. Journal of Personality and Social Psychology, 14, 101-113.

Smith, E. R., \& Miller, F. D. (1978). Limits on perception of cognitive processes: A reply to Nisbett and Wilson. Psychological Review, 85. 355-362.

Snyder, M. (1974). Self-monitoring of expressive behavior. Journal of Personality and Social Psychology, 30, 526-537.

Stone, L. (1977). The family, sex and marriage in England 1500-1800. New York: Harper \& Row.

Sullivan, H. S. (1953). The interpersonal theory of psychiatry. New York: Norton.

Swann, W. B. (1985). The self as architect of social reality. In B. Schlenker (Ed.), The self and social life (pp. 100-125). New York: McGraw-Hill.

Sypher, W. (1962). Loss of self in modern literature and art. New York: Random House.

Tart, C. T. (1969). Altered states of consciousness. New York: Wiley.

Tedeschi, J. T. (Ed.). (1981). Impression management theory and social psychological research. New York: Academic Press.

Trilling, L. (1950). The opposing self. New York: Viking.

Trilling, L. (1955). Freud and the crisis of our culture. Boston: Beacon Press.

Trilling, L. (1971). Sincerity and authenticity. Cambridge, MA: Harvard University Press.

Tuchman, B. W. (1978). A distant mirror. New York: Ballantine.

Veblen, T. (1953). The theory of the leisure class. New York: Mentor. (Original work published 1899)

Weary, G. (1980). Examination of affect and egotism as mediators of bias in causal attributions. Journal of Personality and Social Psychology, 38, 348-357.

Weintraub, K. J. (1978). The value of the individual: Self and circumstance in autobiography. Chicago: University of Chicago Press.

Wheelis, A. (1958). The quest for identity. New York: Norton.

Whyte, L. L. (1960). The unconscious before Freud. New York: Basic Books.

Whyte, W. H. (1956). The organization man. New York: Simon \& Schuster.

Wicklund, R. A. (1975). Objective self-awareness. In L. Berkowitz (Ed.), Advances in experimental social psychology (Vol. 8, pp. 233275). New York: Academic Press.

Wicklund, R. A., \& Gollwitzer, P. M. (1981). Symbolic self-completion, attempted influence, and self-deprecation. Basic and Applied Social Psychology, 2, 89-114.

Wicklund, R. A., \& Gollwitzer, P. M. (1982). Symbolic self-completion. Hillsdale, NJ: Erlbaum.

Received March 2, 1984

Revision received February 28, 1985 